Article

\title{
Nitrogen Recovery and Loss from Kentucky Bluegrass Fertilized by Conventional or Enhanced-Efficiency Urea Granules
}

\author{
Maxim J. Schlossberg * (D), Benjamin A. McGraw, Ryan L. Sebring and Kyle R. Hivner \\ Department of Plant Science, The Pennsylvania State University, University Park, PA 16802, USA; \\ bam53@psu.edu (B.A.M.); rls246@psu.edu (R.L.S.); kyle.hivner@gmail.com (K.R.H.) \\ * Correspondence: mjs38@psu.edu; Tel.: +1-814-863-1015
}

Received: 5 July 2018; Accepted: 7 August 2018; Published: 11 August 2018

\begin{abstract}
Easy handling and low unit N cost make prilled urea (46-0-0) a popular fertilizer. While incomplete recovery of granular urea applications by turfgrass is documented, field evaluations of $\mathrm{NH}_{3}$ volatilization mitigation by coatings or bioinhibitor efficiency enhancements are limited. Meanwhile, $\mathrm{NH}_{3}$ emissions reduce air quality and contribute to nutrient loading of water resources. Our objectives were to quantify 3- and 6-d ammonia emission and 9-week turfgrass recovery of unincorporated granular fertilizer application to turfgrass. In 2014 and 2015, commercial urea-N fertilizers were broadcast over a mature Kentucky bluegrass (Poa pratensis L. 'Midnight') lawn at $43 \mathrm{~kg} \mathrm{ha}^{-1}$. Treatments included conventional urea and three enhanced-efficiency fertilizers; a blended fertilizer with $25 \%$ of its urea-N supplanted by polymer- and polymer-/sulfur-coated prills, or two stabilized urea fertilizers both amended by N-(n-butyl) thiophosphoric triamide (NBPT) and dicyandiamide (DCD) inhibitors. Using a 51\% 'trapping-efficiency' flux chamber system under the field conditions described, 23.1 or $33.5 \%$ of the conventional urea- $\mathrm{N}$ was lost as $\mathrm{NH}_{3}$ over the respective 3- or 6-d period following application. Alternatively, dual amendment by NBPT and DCD resulted in approximately 10.3 or $19.6 \% \mathrm{NH}_{3}-\mathrm{N}$ loss over the respective 3- or 6-d periods, and greater fertilizer- $\mathrm{N}$ recovery by the turfgrass over the 9 -week experiments.
\end{abstract}

Keywords: ammonia; best management practice; turfgrass; urease inhibitor; volatilization

\section{Introduction}

In the presence of nitrate or sulfate, ammonia enhances the formation and growth of airborne particulate that is statistically correlated with adverse human health effects [1-4]. Ammonia deposition to surfaces, the primary atmospheric removal mechanism, is considered a significant threat to terrestrial and aquatic ecosystem health [5,6]. The majority of atmospheric ammonia in the US and Canada originates from livestock operations and fertilizer application $[7,8]$.

Numerous investigations into ammonia loss following urea fertilizer application to turfgrass systems have been summarized [9-11]. Environmental and edaphic conditions shown to directly influence ammonia volatilization from urea fertilizer applications include temperature, wind speed, soil organic matter, and soil pH and moisture levels [12-14]. These and more recent studies have employed varying application and collection methods. As a result, ammonia-N volatilization from turfgrass systems is reported to range from 0.04 to $60 \%$ of urea-N fertilizer applied $[11,13,15-17]$.

While urea fertilizer is subject to several fates following granular application to turfgrass, direct assimilation by plant roots and/or vegetative tissue is most desirable. Diffusion of the diminutive and polar urea molecule into the plant symplast is passive, yet reliant on hydration and a favorable 
concentration gradient [18]. Over a 48-hour period following a foliar urea-N application of $50 \mathrm{~kg} \mathrm{ha}^{-1}$, assimilation by perennial ryegrass (Lolium perenne L.) was observed to exceed $17 \mathrm{~kg} \mathrm{ha}^{-1}$ [19].

Alternatively, urea is hydrolyzed into ammonia and carbon dioxide by urease [20], an enzyme ubiquitous to soil, thatch, and turfgrass leaf and shoot surfaces [21]. The position of urea at hydrolysis significantly influences the fate of its products [10]. Prompt incorporation of granular urea into soil, either mechanically [22-24] or via precipitation/irrigation-facilitated dissolution and infiltration [13,25-27], has been shown to reduce subsequent ammonia volatilization rate. Accordingly, best management practice (BMP) includes prompt but judicious 'watering-in' of urea fertilizer applications to turfgrass $[9,28,29]$.

Yet given the perennial nature of turfgrass, limited availability and/or opportunity often preclude(s) mechanical incorporation and/or irrigation/rainfall concomitance when scheduling granular urea-N fertilization events. To that end, N-(n-butyl) thiophosphoric triamide (NBPT, $\mathrm{C}_{4} \mathrm{H}_{14} \mathrm{~N}_{3} \mathrm{PS}$ ) is one of a few compounds so dependably inhibitive of biological $\mathrm{N}$ transformation that it has been commercially adopted [30]. Under aerobic conditions, this soluble alkane decomposes to $\mathrm{N}$-(n-butyl) phosphorotriamide [31] and inhibits urease activity by forming a tridentate bond that binds its active site [32]. Subsequent meta-analyses indicate NBPT amendment of urea supports a near $50 \%$ relative-reduction in $\mathrm{NH}_{3}$ loss following broadcast application of urea to agricultural and horticultural production systems [33-35]. More recent evaluations assessing $\mathrm{NH}_{3}$ volatilization further confirm benefits of complimenting 100 to $175 \mathrm{~kg} \mathrm{ha}^{-1}$ urea-N applications with $0.2 \%$ NBPT [36-42].

Several laboratory or greenhouse studies have been conducted to evaluate efficacy of NBPT amendment of urea granules applied to turfgrass. One to five weeks following 48 to $50 \mathrm{~kg} \mathrm{ha}^{-1}$ urea-N granular applications, $\mathrm{N}$ recovery in ryegrass or creeping bentgrass (Agrostis stolonifera L.) clippings receiving NBPT-amended treatments exceeded levels observed in urea-fertilized counterparts [22,43]. Likewise, passive measures of $\mathrm{NH}_{3}$ volatilization in the $24 \mathrm{~h}$ following the described urea treatments showed the NBPT additive to reduce $\mathrm{NH}_{3}$ volatilization [43]. A laboratory flux-chamber assessment employing fairway plugs of hybrid bermudagrass (Cynodon dactylon (L.) Pers. $\times$ Cynodon transvaalensis Burtt Davy) was initiated by a $49 \mathrm{~kg} \mathrm{~N} \mathrm{ha}^{-1}$ broadcast application of urea or commercially amended (stabilized) urea fertilizer granules. Following the 7-d evaluation period, $\mathrm{NH}_{3}$ loss from a DCDand NBPT-amended urea accounted for $28 \%$ of the fertilizer-N. Statistically greater $\mathrm{NH}_{3}$ loss from conventional urea or urea combined with calcium aminoethylpiperazine and heteropolysaccharide polymers amounted to 40 to $43 \%$ of the applied N [44].

A comparatively greater number of turfgrass field experiments evaluating NBPT amendment on recovery/loss of granular urea-N fertilizer applications report mixed results. Results of a multi-year Kentucky bluegrass (Poa pratensis L. 'Midnight') field study indicate NBPT amendment of granular urea improved $\mathrm{N}$ recovery by clippings in one out of eight measurements [45]. Following a single-year evaluation of conventional or urease inhibitor-amended granular urea-N application $\left(49 \mathrm{~kg} \mathrm{ha}^{-1}\right)$, no treatment influenced performance, volatilization from, or N-recovery by the Kentucky bluegrass and perennial ryegrass mixed sward [15]. Micrometeorological methods, employed to measure ammonia volatilization 0 - to 10-d following a broadcast application of $112 \mathrm{~kg} \mathrm{~N} \mathrm{ha}^{-1}$ as granular urea, ammonium sulfate, or DCD- and NBPT-amended urea over a burned Kentucky bluegrass seed production field, resulted in volatilization of $15 \%$ of the conventional urea fertilizer application [46]. In absolute percentage terms, 9.3 or $11.1 \%$ less of the respective ammonium sulfate or amended-urea treatments $(p<0.05)$ were simultaneously lost as gas [46].

The estimated area of turfgrass currently managed, yet not necessarily fertilized, in the US is $1.6 \times 10^{7}$ ha [47]. Several regional, state, and/or local government agencies, across the US and the world, have either enacted or drafted laws/ordinances regulating fertilizer application to managed turfgrass [48,49]. Golf course superintendents, sports turf managers, and lawn care operators are committed to worker, player, and client safety, and plant health and effective management of natural resources, and they rely on rapid transfer of practical field research and resulting best management practices (BMP). Our objectives were to quantify 3- and 6-d ammonia emission and fertilizer-N recovery 
over a 9-week period following unincorporated application of conventional or enhanced efficiency granular urea-N fertilizer to an intensively managed Kentucky bluegrass system.

\section{Materials and Methods}

A Hagerstown silt loam (fine, mixed, semiactive, mesic Typic Hapludalfs) was established by Kentucky bluegrass (Poa pratensis L. 'Midnight') sod in September 2012 and subsequently maintained within the Pennsylvania State Univ. Valentine Turfgrass Research Center (University Park, PA, USA). Every $6 \pm 4$ days from May to October 2013 and April to July 2014, the field was mowed at a 3-cm height of cut with clippings collected and discarded. In the 2014 and 2015 seasons, weeds were controlled by manual removal, plots were irrigated as necessary to prevent wilt, and climatic conditions were logged every $15 \mathrm{~min}$ by an onsite weather station.

A 1:1 (by mass) slurry of de-ionized (DI) $\mathrm{H}_{2} \mathrm{O}$ and soil, collected from the upper $15-\mathrm{cm}$ of the profile in April 2014, was extracted and analyzed for $\mathrm{pH}, \mathrm{NO}_{3}-\mathrm{N}$, and $\mathrm{NH}_{4}-\mathrm{N}$ levels [50-52]. Results showed neutral soil $\mathrm{pH}$ (7.0) and undetectable levels of ionic $\mathrm{N}$ forms $\left(<5 \mathrm{mg} \cdot \mathrm{kg}^{-1}\right.$ soil). In May 2014, soluble fertilizers were applied to the Kentucky bluegrass to deliver $25 \mathrm{~kg} \mathrm{~N}, 30 \mathrm{~kg} \mathrm{Mg}$, and $75 \mathrm{~kg} \mathrm{~K} \mathrm{O}$ and $\mathrm{S}$ ha ${ }^{-1}$.

On 24 July 2014, the experimental area was mowed and clippings removed before installing a randomized complete block design comprising six (6) blocks of five (5) plots $1.6 \times 1.0 \mathrm{~m}$ in size. Plots were divided by $0.6-\mathrm{m}$-wide spans on their short boundaries. Chamber installation was initiated on 25 July 2014 by setting a 16.5-cm id schedule 40 poly-vinyl chloride (PVC) end cap within in each plot and repeatedly striking it with a rubber mallet. The resulting indentation in the turf canopy served as a guide to cut a 3-cm-deep trench with a 'sharp-shooter' shovel [53]. The end cap was then firmly seated within the trench to a $2.5-\mathrm{cm}$ depth, removed, and the process repeated on the remaining twenty-nine plots.

At 10:00 on 25 July, a 40-mL aliquot of standard $2 \%$ boric acid $\left(\mathrm{H}_{3} \mathrm{BO}_{3}\right)$ was dispensed into a pre-labeled '0-3-d trip blank' high-density polyethylene (HDPE) bottle and tightly capped. Numbered vials containing pre-weighed, urea-based fertilizer granules; corresponding to the described fertilizer treatments (Table 1) were carefully applied within the chamber 'enclosure area' of a randomly selected plot at the prescribed $43 \mathrm{~kg} \mathrm{ha}^{-1}$ urea-N rate. The treatment was then 'activated' by $0.1-\mathrm{mm} \mathrm{DI}$ $\mathrm{H}_{2} \mathrm{O}\left(1223 \mathrm{~L} \mathrm{ha}^{-1}\right)$ using a single-nozzle, $\mathrm{CO}_{2}$-powered backpack sprayer and an air induction even flat-spray tip (TeeJet AI9508EVS, Spraying Systems Co., Wheaton, IL, USA).

Table 1. Described grade and enhancement of the employed granular fertilizers.

\begin{tabular}{cccccc}
\hline $\begin{array}{c}\text { Urea Fertilizer } \\
\text { Treatment }^{\mathbf{1}}\end{array}$ & $\begin{array}{c}\text { Urea-N } \\
(\mathbf{g ~ k g})\end{array}$ & $\begin{array}{c}\mathbf{P}_{\mathbf{2}} \mathbf{O}_{\mathbf{5}} \\
\mathbf{( g ~ k g )}\end{array}$ & $\begin{array}{c}\mathbf{K}_{\mathbf{2}} \mathbf{O} \\
\mathbf{( g ~ k g )}\end{array}$ & Inhibitor/Additive/Enhancement & $\begin{array}{c}\text { Mass } \\
\text { Fraction } \\
\mathbf{( g ~ k g})\end{array}$ \\
\hline $\mathrm{U}$ & 460 & 0 & 0 & - & - \\
\hline EEF-S1 & 460 & 0 & 0 & $\begin{array}{c}\text { Dicyandiamide (DCD) } \\
\text { N-butyl-thiophosphoric triamide (NBPT) }\end{array}$ & $\begin{array}{c}10.5 \\
0.9\end{array}$ \\
\hline EEF-S2 & 460 & 0 & 0 & $\begin{array}{c}\text { Dicyandiamide (DCD) } \\
\text { N-butyl-thiophosphoric triamide (NBPT) }\end{array}$ & $\begin{array}{c}21.0 \\
0.9\end{array}$ \\
\hline EEF-C & 290 & 20 & 50 & $\begin{array}{c}\text { Slowly available N from polymer- and } \\
\text { polymer-/sulfur-coated urea }\end{array}$ & 72.0 \\
\hline
\end{tabular}

${ }^{1}$ Urea fertilizer treatments: EEF-S1, stabilized urea (UFLEXX), EEF-S2, stabilized urea (UMAXX), Koch Agronomic Services, Wichita, KS, USA; EEF-C, coated-urea/urea blend (STA-GREEN), Pursell's, Sylacauga, AL, USA; U, urea, Alfa-Aesar, Ward Hill, MA, USA.

Immediately following each granular fertilizer activation, a flux chamber was installed on the plot. Each flux chamber was comprised of a PVC endcap modified by a 0.5 -cm-wide by 2.7 -cm-deep notch and two $0.63-\mathrm{cm}$ holes in opposite sides [53]. One hole was fitted with a 3.2-mm od nylon hose connector and sealed by epoxy. The other threaded by a 14-cm length of 3.2-mm id vinyl tube (Tygon®, 
Saint-Gobain, Valley Forge, PA, USA) and its internal end connected to the stem of a $60-\mathrm{mm}$ id, translucent-HDPE funnel. While unquantified, these inlets provided limited illumination of the turfgrass canopy within the flux chambers over the experimental photoperiods. Lastly, each funnel mouth was fastened to the draw-side of a 60-mm case fan (12 VDC, Fanner Tech USA, City of Industry, CA, USA) by two (2) nylon zip-ties and an epoxy seal.

While not immediately activated, the purpose of this case fan was to facilitate intake air mixing, i.e., disruption of laminar flow between the inlet and outlet port of each chamber. The $12 \mathrm{~V}$ supply wires for the fan were run out the $0.5-\mathrm{cm}$-wide notch, and the flux chamber was then driven to a $2.5-\mathrm{cm}$ soil-penetration depth using a rubber mallet. Firm seating of each flux chamber was confirmed by resistance to dislodging efforts and visible pinching of the fan wire jacket between the chamber and vegetation. Using one hand to apply pressure to the top of the flux chamber, the intake hose was then cinched to seal the chamber where the tube expanded over the tapered funnel stem, and the plot number and time recorded.

Once the four fertilizer treatments had been applied, activated, and instrumented to randomly selected plots in a block, the remaining zero- $\mathrm{N}$ 'control' plot was treated with $\mathrm{DI}_{2} \mathrm{O}$ as described above and equipped with a flux chamber. The plot number and time was recorded, and the process initiated on the next block.

Once all treatments were applied and chambers installed, a dispensetter was used to add $80 \mathrm{~mL}$ of stock $2 \%$ standardized boric acid solution to each $250-\mathrm{mL}$ scrubbing flask (Scienceware, Bel-Art Products, Wayne, NJ, USA). The flask intake stem was fitted by a $0.5-\mathrm{m}$ length of $3.2 \mathrm{~mm}$ id vinyl tube, and the flask firmly sealed. Lastly, the described vinyl tube was fastened to the nylon hose connector of its dedicated flux chamber. During the post-treatment filling of gas scrubbing flasks in blocks $\mathrm{B}$, $\mathrm{D}$, and $\mathrm{F}, 80-\mathrm{mL}$ aliquots of boric acid were dispensed directly into '0-3-d trip blank' labeled HDPE bottles and tightly capped.

Three vacuum manifolds, constructed from 0.8-m lengths of 5.1-cm PVC pipe, were placed within block borders and connected to all gas scrubbing flask vacuum stems in adjacent blocks. A 7-m length of 3.2-mm id tube was then used to connect each manifold to a centrally located vacuum splitter fitted with 3.2-mm od nylon hose connectors. A 1.5-m length of thick-walled vacuum hose connected the vacuum splitter to an industrial-grade vacuum pump (DV-142N, JB Industries, Aurora, IL, USA). Once all scrubbing flask/manifold/vacuum splitter connections were secured, the vacuum pump was actuated to draw $142 \mathrm{~L} \cdot \mathrm{min}^{-1}$ over the 6-d experimental period.

Lastly, all case fan power supply wires were connected in two parallel-configured loops. A timer relay (Schneider Electric, LLC, Schaumburg, IL, USA) alternated 12 VDC delivery on 2-minute intervals. Two fully charged 7-Ah batteries connected to either a $60 \mathrm{~W}$ solar panel charging module or a $120 \mathrm{VAC}$ to 12 VDC 4-A transformer (drawing from vacuum pump extension cord) facilitated continual fan operation. During each 6-day period the PVC chambers were in place, the plots were neither mowed nor irrigated.

From 10:00 to 11:30 on 28 July, each plot was revisited in the order of treatment applications $3 \mathrm{~d}$ prior. The vinyl tube connecting the scrubbing flask to the manifold was clamped before unsealing and decanting the boric acid solution into a pre-labeled 120-mL, wide-mouth HDPE bottle. A dispensetter was used to replace $80-\mathrm{mL}$ of stock $2 \%$ standardized boric acid solution to the scrubbing flasks, and each flask was resealed. As 3-d previous, $80-\mathrm{mL}$ aliquots of boric acid were dispensed directly into '3-6-d trip blank' labeled HDPE bottles. All bottles were transported to the laboratory and stored at $4{ }^{\circ} \mathrm{C}$. On 31 July, the gas scrubbing flask contents were again collected as described, and the bottles were tightly capped for subsequent transport and laboratory storage at $4{ }^{\circ} \mathrm{C}$. With the exception of the flux chambers, all volatilization measurement equipment was collected from the plots. The remaining granular fertilizer for each plot treatment; i.e., fertilizer mass required to treat the remaining $1.579 \mathrm{~m}^{2}$ of plot area $\left(1.6 \mathrm{~m}^{2}-2.128 \times 10^{-2} \mathrm{~m}^{2}\right.$ flux chamber area), was applied by hand. Once all non-control plots received their assigned $43 \mathrm{~kg} \mathrm{ha}^{-1}$ urea- $\mathrm{N}$ treatment, the flux chambers were removed and the EEF-C plots were 'activated' by $0.1-\mathrm{mm} \mathrm{DI} \mathrm{H}_{2} \mathrm{O}\left(1223 \mathrm{~L} \mathrm{ha}^{-1}\right)$ as previously described. All other 
plots, including the controls, were 'activated' by $0.1-\mathrm{mm}\left(1223 \mathrm{~L} \mathrm{ha}^{-1}\right)$ of a dilute fertilizer solution supplying $\mathrm{P}_{2} \mathrm{O}_{5}$ and $\mathrm{K}_{2} \mathrm{O}$ at respective rates of $2.97 \mathrm{~kg}$ and $7.41 \mathrm{~kg} \mathrm{ha}^{-1}$. This marked initiation of the full-plot fertilizer-N recovery trial; i.e., zero days after full plot treatment (0 DAFPT).

The plots remained flagged over the subsequent 61-d experiment to prevent inadvertent mowing. Purposefully avoiding the prior location of the flux chamber in each plot, a dedicated rotary deck-mower was used to collect clipping yields at a 3-cm height of cut over a 1.6-m-long and 0.56-m-wide swath on 8, 17, and 26 August $(8,17$, and 26 days after full plot treatment; DAFPT) and 3, 10, 17, and 30 September 2014 (34, 41, 48, and 61 DAFPT). Immediately following these yield measures, all remaining turf was mowed and clippings were collected and discarded offsite. Clippings yields were dried to constant mass in a forced-air oven $\left(65^{\circ} \mathrm{C}\right)$ and transferred to desiccators for storage. Each mass of dry clipping samples was determined at 1-mg resolution and recorded. For each experimental unit, a 1-g subsample from each clipping yield event was ground to pass a $0.5-\mathrm{mm}$ sieve and analyzed for total N [54] by medium temperature furnace combustion (EA-1110 CHNS analyzer, CE Instruments, Milan, Italy).

Each date-specific product of yield and tissue $\mathrm{N}$ was calculated as $\mathrm{N}$ offtake $\left(\mathrm{kg} \mathrm{N} \mathrm{ha}^{-1}\right)$ on a per-plot basis [55] and represents apparent $\mathrm{N}$ recovery for the time period from the last mowing event, either 0 DAT or more recent clipping yield collection. Control-adjusted fertilizer-N recovery for each fertilized experimental unit and date was calculated by subtracting the control plot offtake on a per block basis.

A similar experiment was initiated 4 September 2014 on an adjacent section of the Kentucky bluegrass system. However, the plots were 0.61 -m-square and only the $2.128 \times 10^{-2} \mathrm{~m}^{2}$ flux chamber areas in each plot were fertilized, activated, and instrumented (all as previously described). Likewise, on 7 September, the gas scrubbing flask contents were collected, replaced with $80-\mathrm{mL}$ of stock $2 \%$ standardized boric acid solution, and each flask was resealed. Bottles containing the 0 to 3 -d samples and 3-6-d trip blanks were tightly capped and transferred to the laboratory for storage $\left(4^{\circ} \mathrm{C}\right)$. The gas scrubbing flask contents were again collected on 10 September 2014, transferred into labelled bottles, and stored as described. All volatilization measurement equipment was removed, and no further data was collected from the September experiment.

In 2015, an identical pair of studies was conducted in unique sections of the described Kentucky bluegrass system. The first was initiated 28 July and employed the identical plot number, plot size, fertilizer treatments and methodology as the July 2014 study described above. Following termination of the volatilization measures 3 August 2015, the full-plot fertilizer granules were applied, chambers removed, and treatments activated as described. The plot area remained flagged to prevent inadvertent mowing.

A second volatilization study was initiated the following day, by installation of thirty 0.61-m-square plots in randomized complete block design on an adjacent section of the described system. Flux chamber installation in the center of each was initiated, and only the $2.128 \times 10^{-2} \mathrm{~m}^{2}$ flux chamber areas in each plot were fertilized, activated, and instrumented (all as previously described). On 7 August, the gas scrubbing flask contents were collected, replaced with $80 \mathrm{~mL}$ of stock $2 \%$ standardized boric acid solution, and each flask was resealed. Bottles containing the 0 to $3-\mathrm{d}$ samples and 3-6-d trip blanks were tightly capped and transferred to the laboratory for storage $\left(4^{\circ} \mathrm{C}\right)$. During each 6-day period the PVC chambers were in place, the plots were neither mowed nor irrigated. The gas scrubbing flask contents were again collected on 10 August 2015, transferred into labelled bottles, and stored as described. All volatilization measurement equipment was removed, and no further data was collected from the second 2015 study.

Termination of the first volatilization study 3 August marked initiation of the subsequent 63-d full-plot fertilizer-N recovery trial. The described rotary deck-mower was used to collect clipping yields at a 3-cm height of cut over a 1.6-m-long by 0.56-m-wide swath on 13, 20, and 27 August (10, 17, and 24 DAFPT); 4 and 16 September (32 and 44 DAFPT); and 5 October 2015 (63 DAFPT). Immediately 
following these yield measures, all remaining turf was mowed, and clippings were collected and discarded offsite.

The mean $\mathrm{pH}$ level of the four, field-dispensed, date-specific, $2 \%$ boric acid 'trip blanks' collected from each experiment conducted in 2014 and 2015 was determined in the laboratory. A 15-mL sample of each recovered boric acid solution was decanted into an HDPE beaker, then titrated with standardized $0.01 \mathrm{~N} \mathrm{HCl}$ to its collection-date specific $\mathrm{pH}$ endpoint using a digital burette. The volume of each remaining sample was measured by graduated cylinder and recorded. Titrated $\mathrm{NH}_{3}-\mathrm{N}$ for each flux chamber (per 3-d period) was calculated as shown (Equation (1)).

$$
\left[\begin{array}{c}
\text { titrated NH} \\
\mathrm{kg} \mathrm{ha}^{-1}-\mathrm{N},
\end{array}\right]=\left[\frac{-\mathrm{L} \text { titrant }}{2.13 \times 10^{-6} \mathrm{ha}}\right]\left[\frac{0.01 \mathrm{eq} \mathrm{H}}{\mathrm{L} \mathrm{titrant}}\right]\left[\frac{1.4 \times 10^{-2} \mathrm{~kg} \mathrm{NH}_{3}-\mathrm{N}}{\mathrm{eq} \mathrm{NH}{ }^{+}}\right]
$$

To determine volatilized $\mathrm{NH}_{3}-\mathrm{N}$ from treatment, titrated $\mathrm{NH}_{3}-\mathrm{N}\left(\mathrm{kg} \mathrm{ha}^{-1}\right)$ was multiplied by its specific ratio of collected-to-titrated boric acid, then corrected for background $\mathrm{NH}_{3}-\mathrm{N}$ by subtracting volatilized $\mathrm{NH}_{3}-\mathrm{N}$ measured from the control plot within its experiment block. Lastly, fertilizer-N volatilized as $\mathrm{NH}_{3}\left(\mathrm{~kg} \mathrm{ha}^{-1}\right)$ is the product of volatilized $\mathrm{NH}_{3}-\mathrm{N}$ from treatment and the chamber efficiency multiplier (1.965, Appendix A).

The 41- and 48-DAFPT clipping yields and $\mathrm{N}$ offtakes measured in 2014 were summed to standardize the number of data collection events over both experiments. All repeated measures of volatilized $\mathrm{NH}_{3}-\mathrm{N}(n=192)$, clipping yield $(n=360), \mathrm{N}$ offtake $(n=360)$, or fertilizer- $\mathrm{N}$ recovery $(n=288)$ dependent variables were combined for global analysis using the MIXED procedure (SAS Institute, v. 8.2). The employment of identical treatment levels and similar cultural, climatic, and edaphic conditions compelled the designation of 'experiment', and all subsequent interaction terms were designated as random variables. Significance of N-fertilizer treatment effect (TRT) was F-tested by the expected mean squares of its respective experiment interaction term, while the DAIT or DAFPT effect and its interaction with TRT was F-tested by the residual [56].

\section{Results}

Mean, maximum, and minimum air temperature recorded over the four 6-d ammonia volatilization collection periods ranged from 20.6 to $23.5,28.5$ to 33.5 , and 10.0 to $14.1 \mathrm{C}$, respectively. Water-tight containers were employed to protect $\mathrm{AC}$ wiring and vacuum pump connections during respective 1.9-, 1.3-, and 1.0-cm precipitation events occurring 28 July, 30 July, and 6 September 2014, as well as during a 1.5-cm precipitation event occurring 30 July 2015.

Adjusted for chamber efficiency and 0- to 3-d following initiation, flux-chamber mean ammonia-N volatilization from control (unfertilized) plots was $0.080 \mathrm{~kg} \mathrm{ha}^{-1}$, with measures observed over a range of 0 to $0.417 \mathrm{~kg} \mathrm{ha}^{-1}$. From 3- to 6-d following initiation, the flux-chamber mean ammonia-N volatilization from the control (unfertilized) plots was $0.124 \mathrm{~kg} \mathrm{ha}^{-1}$, with measures ranging from 0 to $0.831 \mathrm{~kg} \mathrm{ha}^{-1}$.

\subsection{Volatilization of Urea Fertilizer Nitrogen as Ammonia}

Fertilizer- $\mathrm{N}$ volatilized as $\mathrm{NH}_{3}$ was influenced by the main effect of fertilizer treatment (TRT), days after initial treatment (DAIT), and their interaction (Table 2). 
Table 2. Analysis of variance by fixed effect and dependent variable. Mean separation of clipping yield and $\mathrm{N}$ offtake, and cumulative fertilizer- $\mathrm{N}$ volatilized as $\mathrm{NH}_{3}$ or recovered in clippings, by fertilizers. EEF-S1, stabilized urea (UFLEXX), EEF-S2, stabilized urea (UMAXX), EEF-C, coated-urea/urea blend (STA-GREEN).

\begin{tabular}{|c|c|c|c|c|c|c|c|c|c|c|}
\hline \multirow{3}{*}{ Source } & \multicolumn{4}{|c|}{ Clipping } & \multicolumn{6}{|c|}{ Fertilizer-N } \\
\hline & \multicolumn{2}{|c|}{ df } & yield & N offtake & \multicolumn{2}{|c|}{ df } & \multirow{2}{*}{$\begin{array}{c}\text { Volatilized as NH3 } \\
P(\text { FR }<\text { Fcrit })\end{array}$} & \multicolumn{2}{|c|}{ df } & \multirow{2}{*}{$\begin{array}{c}\text { Recovered in clippings } \\
P(\mathrm{FR}<\mathrm{Fcrit})\end{array}$} \\
\hline & num & den & \multicolumn{2}{|c|}{$P($ FR $<$ Fcrit $)$} & num & den & & num & den & \\
\hline TRT & 4 & 4 & $<0.0001$ & $<0.0001$ & 3 & 9 & 0.0002 & 3 & 3 & 0.0329 \\
\hline DAFPT/DAIT $^{1}$ & 5 & 315 & $<0.0001$ & $<0.0001$ & 1 & 152 & $<0.0001$ & 5 & 250 & $<0.0001$ \\
\hline \multirow[t]{2}{*}{ TRT X DAFPT/DAIT } & 20 & 315 & 0.4980 & 0.2744 & 3 & 152 & $<0.0001$ & 15 & 250 & 0.9702 \\
\hline & & & \multicolumn{2}{|c|}{ Mean clipping } & \multicolumn{6}{|c|}{ Cumulative fertilizer-N } \\
\hline \multicolumn{3}{|c|}{ Nitrogen fertilizer TRT } & yield & N offtake & & & Volatilized as NH3 & & & Recovered in clippings \\
\hline & & & \multicolumn{2}{|c|}{$\mathrm{kg} \mathrm{ha}^{-1}$} & & & $\mathrm{~kg} \mathrm{ha}^{-1}$ & & & $\mathrm{~kg} \mathrm{ha}^{-1}$ \\
\hline EEF-S1 & & & 220.3 & 10.0 & & & $8.3(19.3 \%)$ & & & $31.1(72.4 \%)$ \\
\hline EEF-S2 & & & 219.5 & 10.1 & & & $8.6(19.9 \%)$ & & & $31.3(72.9 \%)$ \\
\hline EEF-C & & & 209.8 & 9.5 & & & $11.0(25.6 \%)$ & & & $28.3(65.8 \%)$ \\
\hline Urea & & & 206.7 & 9.3 & & & $14.4(33.5 \%)$ & & & $26.9(62.5 \%)$ \\
\hline Control & & & 119.2 & 4.9 & & & - & & & - \\
\hline $\mathrm{LSD}^{2} \mathrm{a}=0.05$ & & & 7.13 & 0.60 & & & 1.99 & & & 2.76 \\
\hline
\end{tabular}

${ }^{1}$ DAFPT, days after full-plot treatment; DAIT, days after initial treatment. ${ }^{2}$ LSD, least significant difference. 
The main effect of DAIT revealed that $6.49 \mathrm{~kg} \mathrm{ha}^{-1}$ fertilizer-N volatilized over the 0 - to 3 -d period following unincorporated applications of granular fertilizer, a greater emission than the mean value of $4.07 \mathrm{~kg} \mathrm{ha}^{-1}$ observed over the 3- to 6-d period.

The main effect means of fertilizer-N volatilized as $\mathrm{NH}_{3}$ and the associated Fisher's Protected least significant difference (LSD, $5 \%$ ) were multiplied by two for presentation as cumulative fertilizer-N volatilized as $\mathrm{NH}_{3}$ (Table 2). Cumulative fertilizer-N loss from conventional urea over the 6-d period totaled $14.4 \mathrm{~kg} \mathrm{ha}^{-1}$, amounting to $33.5 \%$ of the original $43 \mathrm{~kg}$ urea- $\mathrm{N} \mathrm{ha}^{-1}$ application. Over the same period, cumulative fertilizer-N loss from the original $43 \mathrm{~kg} \mathrm{ha}^{-1}$ EEF-C fertilizer application totaled $11.0 \mathrm{~kg} \mathrm{ha}^{-1}(25.6 \%)$. Cumulative $0-$ to $6-\mathrm{d}$ ammonia-N loss from the respective EEF-S1 or -S2 fertilizer treatment totaled 8.3 or $8.55 \mathrm{~kg} \mathrm{ha}^{-1}$ and comprised, on average, $19.6 \%$ of the original $43 \mathrm{~kg}$ urea-N ha ${ }^{-1}$ application (Table 2).

All granular treatments released over half the total amount of fertilizer- $\mathrm{N}$ volatilized within $3 \mathrm{~d}$ (Figure 1). This was most apparent of the 0 -to $3-\mathrm{d} \mathrm{NH} \mathrm{NH}_{3}$ emission resulting from unincorporated application of conventional urea. This emission equaled $9.95 \mathrm{~kg} \mathrm{ha}^{-1}$ and exceeded that of all other fertilizer treatments (Figure 1). Fertilizer-N volatilization from the EEF-C fertilizer, 0- to 3-d following unincorporated application, equaled $7.12 \mathrm{~kg} \mathrm{ha}^{-1}$ and exceeded the dual-inhibitor-enhanced fertilizer treatments (Figure 1). Ammonia-N volatilization, 0 - to 3-d following unincorporated applications of the EEF-S1 and -S2 fertilizers, were similar and averaged $4.45 \mathrm{~kg} \mathrm{ha}^{-1}$. Between 3.87 and $4.47 \mathrm{~kg} \mathrm{ha}^{-1}$ of fertilizer- $\mathrm{N}$ was measured as volatilized $\mathrm{NH}_{3}$ over the 3- to 6-d period following broadcast application, yet no differences among fertilizer treatments were observed (Figure 1).

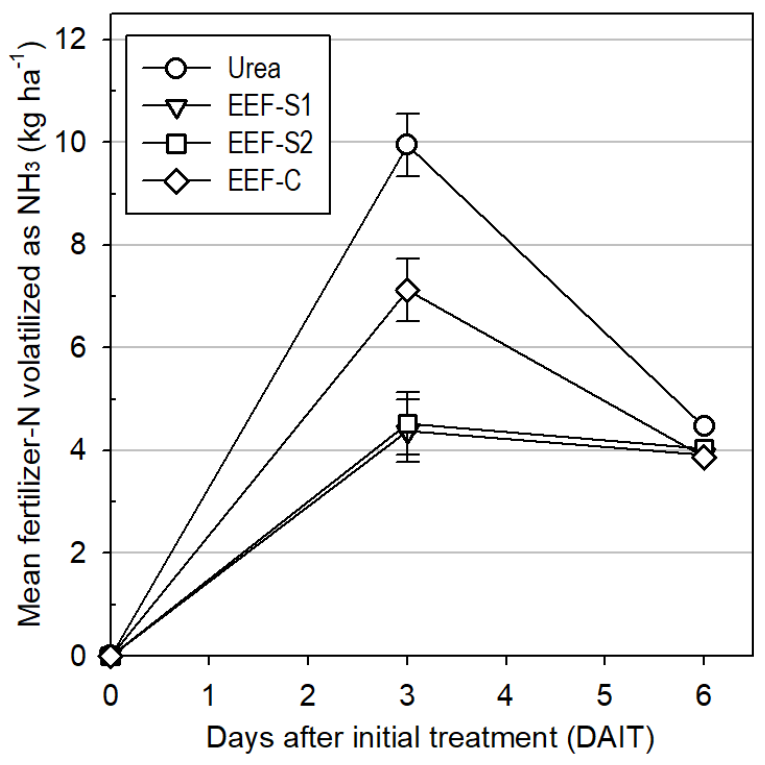

Figure 1. Mean ammonia volatilization by days after initial treatment (DAIT) and fertilizer; EEF-S1, stabilized urea (UFLEXX), EEF-S2, stabilized urea (UMAXX), EEF-C, coated-urea/urea blend (STA-GREEN). Where present, error bars designate the least significant difference (LSD) at a $0.05 \alpha$-level.

\subsection{Turfgrass Growth and Recovery of Fertilizer Nitrogen}

The N-limited status of the Kentucky bluegrass system over the two experimental seasons is confirmed by the observed disparity in mean clipping yield and $\mathrm{N}$ offtake $\left(\mathrm{kg} \mathrm{ha}^{-1}\right)$ between fertilized and unfertilized (control) plots (Table 2). Across all fertilizer treatments and over the 9-week clipping yield collection period, 62.5 to $72.9 \%$ of the fertilizer-N was recovered. The EEF-S1 and -S2 treatments resulted in greater mean clipping yield and cumulative fertilizer-N recovered in clippings than the EEF-C and conventional urea fertilizer treatments (Table 2). 
While fertilizer treatment did not interact with days to influence clipping yield or fertilizer-N recovery, the EEF-C treatment resulted in 30\% less clipping yield than all other treatments 8- to 10-DAFPT. Likewise, the EEF-C-treated plots showed clipping yield and cumulative fertilizer-N recovered in clippings that equaled or exceeded levels simultaneously observed of EEF-S1 and -S2 fertilized plots 41- to 63-DAFPT (data not shown). These results were not unexpected, given that fertilizer prill coatings, whether sulfur and/or polymer, are engineered to delay dissolution of the soluble N source within [9].

\section{Discussion}

Flux chamber field measures of 0 - to 6-d percent ammonia-N loss in the current field study agree with values published using micrometeorological or flux chamber field measures following granular urea-N treatment of turfgrass or pasture at similar or heavier application rates. Over two repeated 8-d periods initiated by $100 \mathrm{~kg}$ urea- $\mathrm{N} \mathrm{ha}^{-1}$ granular fertilizer applications to a Kentucky bluegrass and creeping red fescue (Festuca rubra (L.) ssp. rubra Gaudin) lawn mixture, volatilization losses of 6.7 to $15.1 \%$ of the applied fertilizer-N were observed [27]. Ten days following granular urea treatment of hybrid bermudagrass or zoysiagrass (Zoysia japonica Steud.) sod fields, cumulative ammonia-N volatilization losses were observed to range from 11.7 to $20.1 \%$ of the original $146 \mathrm{~kg}$ urea- $\mathrm{N} \mathrm{ha}{ }^{-1}$ application [17]. Over nine experiments initiated by $30 \mathrm{~kg}$ urea- $\mathrm{N}$ ha ${ }^{-1}$ granular fertilizer applications to a ryegrass and white clover (Trifolium repens L.) pasture [57], 8-day cumulative ammonia-N losses between 7.4 and $20.2 \%$ of urea- $\mathrm{N}$ applied resulted.

Given fertilizer prill coatings, whether sulfur and/or polymer, are engineered to delay dissolution of soluble $\mathrm{N}$ sources within, reduced volatilization from the EEF-C treatment relative to conventional urea was expected [9]. In an un-mowed 10-d lab incubation, reduction in $\mathrm{NH}_{3}$ volatilization from sulfur- or polymer-coated urea fertilizer treatments were observed relative to conventional urea. More specifically, the polymer-coated urea fertilizer evaluated in that lab study resulted in zero $\mathrm{NH}_{3}$ emission [16]. The EEF-C fertilizer employed in this field study contained $24.8 \%$ of a polymer- and polymer-/sulfur-coated urea-N (Table 1) sourced from the same producer. Not unexpectedly, the EEF-C fertilizer treatment emitted $23.6 \%$ less cumulative $\mathrm{NH}_{3}$ than the conventional urea treatment over $6 \mathrm{~d}$ of field measures (Table 2).

Under the described conditions, and relative to identical application of conventional urea, both NBPT- and DCD-amended EEF-S fertilizers reduced cumulative fertilizer-N volatilization by a mean absolute percentage of 13.9. These results are consistent with those of a field study measuring $\mathrm{NH}_{3}$ volatilization over a 4-d period following four monthly applications of $49 \mathrm{~kg}$ urea- $\mathrm{N}$ amended with $0,0.245,0.49$, or $0.98 \mathrm{~kg} \mathrm{NBPT}$ per hectare $(0.5,1$, or $2 \%$ by mass) [58]. Amendment by NBPT resulted in an $11 \%$ mean absolute reduction in fertilizer-N volatilized as $\mathrm{NH}_{3}$. Perhaps of greater noteworthiness, the $13.9 \%$ absolute reduction observed herein resulted from only $0.09 \%$ NBPT amendment of the granular urea.

Increased recovery of NBPT-amended fertilizer observed in our study agrees with published reports. For example, five weeks after fertilizing perennial ryegrass pots with solutions supplying $56.6 \mathrm{~kg} \mathrm{ha}^{-1}$ urea-N, either alone or in combination with NBPT, phenyl-phosphorodiamidate, or hydroquinone, mean N recovery in shoots receiving urea + NBPT exceeded levels observed in all other treated pots [59]. Likewise, over 4 weeks following monthly applications of a $49 \mathrm{~kg}$ urea-N amended with $0.5,1$, or $2 \%$ NBPT by mass, increased Kentucky bluegrass clipping yield was observed relative to urea alone [58]. In a follow-up study, and 6 weeks following $49 \mathrm{~kg} \mathrm{ha}^{-1}$ urea-N applications to Kentucky bluegrass field plots, $0.25 \%$ amendment of urea-N by NBPT resulted in greater plant recovery and soil availability of fertilizer-N than urea alone [60].

\section{Conclusions}

Turfgrass requires greater quantities of $\mathrm{N}$ than any other mineral nutrient, and $\mathrm{N}$ sufficiency is promptly supported by application of soluble $\mathrm{N}$ fertilizer(s) like urea. Current best 
management practices (BMPs), e.g., 'soil incorporation' of urea fertilizer by cultivation, coincidental rainfall or scheduled irrigation event(s), may be precluded by inopportunity or playability requirements. When such circumstances prevail over a 3- or 6-d period following broadcast application, this field research shows commercial NBPT+DCD-amendment of urea prevents respective volatilization of 5.5 or $6.0 \mathrm{~kg} \mathrm{NH}_{3}-\mathrm{N} \mathrm{ha}^{-1}$, and indeed enhances $\mathrm{N}$-fertilizer efficiency. Likewise, and under the described conditions, supplanting $25 \%$ of conventional urea- $\mathrm{N}$ with polymer- and polymer-/sulfur-coated urea prevents volatilization of 2.8 or $3.4 \mathrm{~kg} \mathrm{NH}_{3}-\mathrm{N} \mathrm{ha}^{-1}$ over the respective 3- or 6-d period following broadcast application. If no other soluble $\mathrm{N}$-fertilizer source is available to support a critically important granular application under the described conditions, then employ of a NBPT+DCD-amended urea fertilizer constitutes a recommended best management practice, particularly in PM2.5 (particulate matter, $<2.5 \mu \mathrm{m}$ ) non-attainment regions.

Supplementary Materials: The following are available online at http:/ /www.mdpi.com/2073-4395/8/8/144/s1, Dataset S1: NH3Voltile.csv, Dataset S2: TURFcy_Noff.csv.

Author Contributions: Conceptualization, M.S., K.H. and R.S.; Data Curation, K.H. and R.S.; Formal Analysis, B.M. and M.S.; Funding Acquisition, M.S.; Investigation, M.S., K.H. and R.S.; Methodology, M.S., K.H., and R.S.; Project Administration, B.M. and M.S.; Resources, M.S.; Supervision, B.M. and M.S.; Validation, B.M. and M.S.; Visualization, B.M.; Writing-Original Draft Preparation, M.S., K.H. and R.S.; Writing-Review \& Editing, B.M.

Funding: This work was supported by the USDA National Institute of Food and Agriculture, Hatch project 1006804; Koch Agronomic Services, LLC; and the Pennsylvania Turfgrass Council.

Conflicts of Interest: The authors declare no conflict of interest. The funders had no role in the design of the study; in the collection, analyses, or interpretation of data; in the writing of the manuscript, and in the decision to publish the results.

\section{Appendix A.}

Appendix A.1. Trapping-Efficiency Trial Methods

In July 2016, a completely randomized design of six plots, $1.0-\times 0.8-\mathrm{m}$ in size, was installed in a similarly maintained turfgrass lawn within the Valentine Turfgrass Research Center. Each plot was marked and prepared for a chamber seating as described in the Materials and Methods section. Three randomly selected plots were prepared exactly as the described unfertilized (control treatment) flux chamber plots. The remaining three plots housed a flux trapping-efficiency chamber.

The flux trapping-efficiency chambers were modified by installation of a rubber septum on the opposite end of the intake tube and case fan. A 20-mL HDPE beaker was filled with $15 \mathrm{~mL}$ of $0.227 \mathrm{M}$ $\left(\mathrm{NH}_{4}\right)_{2} \mathrm{SO}_{4}$ and set within the circular chamber trench to reside directly beneath the rubber septum. The beaker was then covered by the flux trapping-efficiency chamber, and the chamber driven to a 2.5-cm soil-penetration depth using a rubber mallet.

Scrubbing flask preparation and tube connections were conducted as described previously. A hypodermic needle containing $3 \mathrm{~mL}$ of $10 \mathrm{M} \mathrm{KOH}$ was then inserted into the septum, and its contents emptied into the beaker containing $\left(\mathrm{NH}_{4}\right)_{2} \mathrm{SO}_{4}$. Thus, three replicate control flux chambers and three flux trapping-efficiency chambers were fully prepared prior to activating the vacuum pump in July 2016. Complete volatilization of $\mathrm{N}$ from the $\left(\mathrm{NH}_{4}\right)_{2} \mathrm{SO}_{4}$ aliquot would generate the equivalent of $43 \mathrm{~kg} \mathrm{ha}^{-1} \mathrm{NH}_{3}-\mathrm{N}$ within the head space of each trapping-efficiency chamber.

\section{Appendix A.2. Trapping-Efficiency Trial Results}

The mean volatilized ammonia recovered in the flux-chamber trapping-efficiency trial $(n=3)$, once corrected for mean 'background' ammonia simultaneously collected from unfertilized plots using conventional flux chambers, was $21.88 \mathrm{~kg} \mathrm{ha}^{-1}$. Assuming complete conversion of $\mathrm{NH}_{4}{ }^{+}$to $\mathrm{NH}_{3}$ within the $15-\mathrm{mL}$ aliquots of $0.227 \mathrm{M}\left(\mathrm{NH}_{4}\right)_{2} \mathrm{SO}_{4}$ over the 0 - to 3-d period, the trapped quantities of ammonia-N signify a mean efficiency ( $\pm 95 \%$ confidence interval) of $50.9 \%( \pm 16.4 \%)$ for the respective static- or flux-chamber systems. The reciprocal of the trapping efficiency determined for the described flux chamber system equals 1.965 . 


\section{References}

1. Brook, R.D.; Rajagopalan, S.; Pope, C.A., III; Brook, J.R.; Bhatnagar, A.; Diez-Roux, A.V.; Holguin, F.; Hong, Y.; Luepker, R.V.; Mittleman, M.A.; et al. Particulate matter air pollution and cardiovascular disease: An update to the scientific statement from the American Heart Association. Circulation 2010, 121, 2331-2378. [CrossRef] [PubMed]

2. Holst, G.J.; Thygesen, M.; Pedersen, C.B.; Peel, R.G.; Barndt, J.; Christiensen, J.H.; Bonlokke, J.; Hertel, O.; Sigsgaard, T. Atmospheric ammonia, ammonium and incident asthma-A nationwide case-control study in Danish preschool children. Eur. Respir. J. 2017, 50, OA502. [CrossRef]

3. Paulot, F.; Jacob, D.J. Hidden cost of U.S. agricultural exports: Particulate matter from ammonia emissions. Environ. Sci. Technol. 2014, 48, 903-908. [CrossRef] [PubMed]

4. Stokstad, E. Ammonia pollution from farming may exact hefty health costs. Science 2014, 343, 238. [CrossRef] [PubMed]

5. Dennis, R.L.; Schwede, D.B.; Bash, J.O.; Pleim, J.E.; Walker, J.T.; Foley, K.M. Sensitivity of continental United States atmospheric budgets of oxidized and reduced nitrogen to dry deposition parametrizations. Philos. Trans. R. Soc. Lond. B Biol. Sci. 2013, 368, 1621. [CrossRef] [PubMed]

6. $\quad$ Ellis, R.A.; Jacob, D.J.; Sulprizio, M.P.; Zhang, L.; Holmes, C.D.; Schichtel, B.A.; Blett, T.; Porter, E.; Pardo, L.H.; Lynch, J.A. Present and future nitrogen deposition to national parks in the United States: Critical load exceedances. Atmos. Chem. Phys. 2013, 13, 9083-9095. [CrossRef]

7. Bittman, S.; Sheppard, S.C.; Hunt, D. Potential for mitigating atmospheric ammonia in Canada. Soil Use Manag. 2017, 33, 263-275. [CrossRef]

8. Pinder, R.W.; Adams, P.J.; Pandis, S.N.; Gilliland, A.B. Temporally resolved ammonia emission inventories: Current estimates, evaluation tools, and measurement needs. J. Geophys. Res. 2006, 111, D16310. [CrossRef]

9. Carrow, R.N.; Waddington, D.V.; Rieke, P.E. Turfgrass Soil Fertility and Chemical Problems: Assessment and Management; John Wiley \& Sons: Hoboken, NJ, USA, 2001; pp. 306-318. ISBN 1-57504-153-7.

10. Petrovic, A.M. The fate of nitrogenous fertilizers applied to turfgrass. J. Environ. Qual. 1990, 19, 1-14. [CrossRef]

11. Turner, T.R.; Hummel, N.W., Jr. Nutritional requirements and fertilization. In Turfgrass-Agronomy Monograph; Carrow, R.N., Shearman, R.C., Waddington, D.V., Eds.; ASA-CSSA-SSSA: Madison, WI, USA, 1992; No. 32; pp. 385-440. ISBN 0-89118-108-3.

12. Hargrove, W.L. Evaluation of ammonia volatilization in the field. J. Prod. Agric. 1988, 1, 104-111. [CrossRef]

13. Titko, S., III; Street, J.R.; Logan, T.J. Volatilization of ammonia from granular and dissolved urea applied to turfgrass. Agron. J. 1987, 79, 535-540. [CrossRef]

14. Torello, W.A.; Wehner, D.J.; Turgeon, A.J. Ammonia volatilization from fertilized turfgrass stands. Agron. J. 1983, 75, 454-457. [CrossRef]

15. Henning, S.W.; Branham, B.E.; Mulvaney, R.L. Response of turfgrass to urea-based fertilizers formulated to reduce ammonia volatilization and nitrate conversion. Biol. Fertil. Soils 2013, 49, 51-60. [CrossRef]

16. Knight, E.C.; Guertal, E.A.; Wood, C.W. Mowing and nitrogen source effects on ammonia volatilization from turfgrass. Crop Sci. 2007, 51, 1628-1634. [CrossRef]

17. Knight-Huckaby, E.C.; Wood, C.W.; Guertal, E.A. Nitrogen source effects on ammonia volatilization from warm-Season sod. Crop Sci. 2012, 52, 1379-1384. [CrossRef]

18. Kojima, S.; Bohner, A.; von Wiren, N. Molecular mechanisms of urea transport in plants. J. Membrane Biol. 2006, 212, 83-91. [CrossRef] [PubMed]

19. Bowman, D.C.; Paul, J.L. Foliar absorption of urea, ammonium, and nitrate by perennial ryegrass turf. J. Am. Soc. Hortic. Sci. 1992, 117, 75-79.

20. Chin, W.; Kroontje, W. Urea hydrolysis and subsequent loss of ammonia. Soil Sci. Soc. Am. J. 1963, 27, 316-318. [CrossRef]

21. Torello, W.A.; Wehner, D.J. Urease activity in a Kentucky bluegrass turf. Agron. J. 1983, 75, 654-656. [CrossRef]

22. Bernardi, A.C.C.; Mota, E.P.; Cardosa, R.D.; Monte, M.B.M.; Oliveira, P.P.A. Ammonia volatilization from soil, dry-matter yield, and nitrogen levels of Italian ryegrass. Comm. Soil Sci. Plant Anal. 2014, 45, 153-162. [CrossRef] 
23. Rochette, P.; Angers, D.A.; Chantigny, M.H.; MacDonald, J.D.; Gasser, M.O.; Bertrand, N. Reducing ammonia volatilization in a no-till soil by incorporating urea and pig slurry in shallow bands. Nutr. Cycl. Agroecosyst. 2009, 84, 71-80. [CrossRef]

24. Sigunda, D.O.; Janssen, B.H.; Oenema, O. Ammonia volatilization from vertisols. Eur. J. Soil Sci. 2002, 53, 195-202. [CrossRef]

25. Bowman, D.C.; Paul, J.L.; Davis, W.B.; Nelson, S.H. Reducing ammonia volatilization from Kentucky bluegrass turf by irrigation. HortScience 1987, 22, 84-87.

26. Holcomb, J.C.; Sullivan, D.M.; Horneck, D.A.; Clough, G.H. Effect of irrigation rate on ammonia volatilization. Soil Sci. Soc. Am. J. 2011, 75, 2341-2347. [CrossRef]

27. Sheard, R.W.; Beauchamp, E.G. Aerodynamic measurement of ammonium volatilization from urea applied to bluegrass fescue turf. In Proceedings of the Fifth International Turfgrass Research Conference; Lemaire, F., Ed.; INRA: Paris, France, 1985; pp. 549-556.

28. Landschoot, P. Turfgrass fertilization-A basic guide for professional turfgrass managers. Doc. UC184. PennState Extension, Penn State University, University Park. 2018. Available online: https:/ / extension.psu. edu/turfgrass-fertilization-a-basic-guide-for-professional-turfgrass-managers (accessed on 5 July 2018).

29. Virginia Golf Course Superintendents Association (VGCSA). Environmental Best Management Practices for Virginia's Golf Courses; VGCSA: Glen Allen, VA, USA, 2012; pp. 67-78. Available online: https://cdn. cybergolf.com/images/373/Virginia-BMP-Full-Report-final.pdf (accessed on 5 July 2018).

30. Kiss, S.; Simihaian, M. Improving Efficiency of Urea Fertilizers by Inhibition of Soil Urease Activity; Kluwer Academic Publishers: Norwell, MA, USA, 2002; pp. 142-419. ISBN 1-4020-0493-1.

31. McCarty, G.W.; Bremner, J.M.; Chai, H.S. Effect of $N$-(n-butyl) thiophosphoric triamide on hydrolysis of urea by plant, microbial, and soil urease. Biol. Fertil. Soils 1989, 8, 123-127. [CrossRef]

32. Manunza, B.; Deiana, S.; Pintire, M.; Gessa, C. The binding mechanism of urea, hydroxamic acid and $\mathrm{N}$-(N-butyl)-phosphoric triamide to the urease active site: A comparative molecular dynamics study. Soil Biol. Biochem. 1999, 31, 789-796. [CrossRef]

33. Abalos, D.; Jeffery, S.; Sanz-Cobena, A.; Guardia, G.; Vallejo, A. Meta-analysis of the effect of urease and nitrification inhibitors on crop productivity and nitrogen use efficiency. Agric. Ecosyst. Environ. 2014, 189, 136-144. [CrossRef]

34. Pan, B.; Lam, S.K.; Mosier, A.; Luo, Y.; Chen, D. Strategies for mitigating ammonia emissions from agroecosystems. In Solutions to Improve Nitrogen Use Efficiency for the World; INI: Melbourne, Australia, 2016; Available online: http:/ / www.ini2016.com/pdf-papers/INI2016_Pan_Baobao.pdf (accessed on 5 July 2018).

35. Silva, A.G.B.; Sequeira, C.H.; Sermarini, R.A.; Otto, R. Urease inhibitor NBPT on ammonia volatilization and crop productivity: A meta-analysis. Agron. J. 2017, 109, 1-13. [CrossRef]

36. Cantu, R.R.; Aita, C.; Doneda, A.; Giacomini, D.A.; Dessbesell, A.; Arenhardt, M.; De Bastiani, G.G.; Pujol, S.B.; Rochette, P.; Chantigny, M.H.; et al. Alternatives to regular urea for abating N losses in lettuce production under sub-tropical climate. Biol. Fertil. Soils 2017, 53, 589-599. [CrossRef]

37. Del Moro, S.K.; Sullivan, D.M.; Horneck, D.A. Ammonia volatilization from broadcast urea and alternative dry nitrogen fertilizers. Soil Sci. Soc. Am. J. 2018, 81, 1629-1639. [CrossRef]

38. Engel, R.; Jones, C.; Romero, C.; Wallander, R. Late-fall, winter and spring broadcast applications of urea to no-till winter wheat I. Ammonia loss and mitigation by NBPT. Soil Sci. Soc. Am. J. 2017, 81, 322-330. [CrossRef]

39. Martins, M.R.; Sant'Anna, S.A.C.; Zaman, M.; Santos, R.C.; Monteiro, R.C.; Alves, B.J.R.; Jantalia, C.P.; Boddey, R.M.; Urquiaga, S. Strategies for the use of urease and nitrification inhibitors with urea: Impact on $\mathrm{N} 2 \mathrm{O}$ and $\mathrm{NH} 3$ emissions, fertilizer-15N recovery and maize yield in a tropical soil. Agric. Ecosyst. Environ. 2017, 247, 54-62. [CrossRef]

40. Mira, A.B.; Cantarella, H.; Souza-Netto, G.J.M.; Moreira, L.A.; Kamogawa, M.Y.; Otto, R. Optimizing urease inhibitor usage to reduce ammonia emission following urea application over crop residues. Agric. Ecosyst. Environ. 2017, 248, 105-112. [CrossRef]

41. Raymond, J.E.; Fox, T.R.; Strahm, B.D.; Zerpa, J. Ammonia volatilization following nitrogen fertilization with enhanced efficiency fertilizers and urea in loblolly pine (Pinus taeda L.) plantations of the southern United States. For. Ecol. Manag. 2016, 376, 247-255. [CrossRef]

42. Sunderlage, B.; Cook, R.L. Soil property and fertilizer additive effects on ammonia volatilization from urea. Soil Sci. Soc. Am. J. 2018, 82, 253-259. [CrossRef] 
43. Soldat, D. Effects of N-(nbutyl) thiophoshoric triamide (NBTP) and dicyandiamide (DD) on the efficacy of urea applied to turfgrass. Grass Roots 2001, July/August, 20-25.

44. Guertal, B. Evaluations of new turfgrass fertilizers: Field and laboratory studies. TERO 2014, 13, 41-45.

45. Waddington, D.V.; Landschoot, P.J.; Clark, J.M.; Fidanza, M.A. Evaluation of liquid nitrogen sources and the urease inhibitor (N-(n-butyl) thiophosphoric-triamide on Kentucky bluegrass turf. Intl. Turfgrass Soc. Res. J. 1993, 7, 572-579.

46. Holcomb, J.C. Enhanced efficiency nitrogen fertilizers for nitrogen management in the Columbia Basin. M.S. Thesis, Oregon State University, Corvallis, OR, USA, 2011.

47. Milesi, C.; Elvidge, C.D.; Dietz, J.B.; Tuttle, B.T.; Nemani, R.R.; Running, S.W. A Strategy for Mapping and Modeling the Ecological Effects of US Lawns; ISPRS: Tempe, AZ, USA, 2005; pp. 1-6. Available online: http:/ / www.isprs.org/proceedings /XXXVI/8-W27/milesi.pdf (accessed on 8 August 2018).

48. Hall, R. Fertilization in regulators' crosshairs: LCOs must remain alert and ready to defend the products they use. Turf 2015, 28, B6, B8, B10.

49. Mitchell, A. Regional rules on nutrient management: It pays to check local requirements when applying nutrients. N. Z. Turf Manag. J. 2016, 33, 30-32.

50. Hartz, T.K.; Smith, R.F.; LeStrange, M.; Schulbach, K.F. On-farm moitoring of soil and crop nitrogen status by nitrate-selective electrode. Commun. Soil Sci. Plant Anal. 1993, 24, 2607-2615. [CrossRef]

51. Molins-Legua, C.; Meseguer-Lloret, S.; Moliner-Martinez, Y.; Campins-Falco, P. A guide for selecting the most appropriate method for ammonium determination in water analysis. Trac-Trends Anal. Chem. 2006, 25, 282-290. [CrossRef]

52. Thomas, G.W. Soil pH and soil acidity. In Methods of Soil Analysis: Part 3-Chemical Analysis; Sparks, D.L., Ed.; Soil Science Society of America; American Society of Agronomy: Madison, WI, USA, 1996.

53. Schlossberg, M.J.; McGraw, B.A.; Hivner, K.R.; Pruyne, D.T. Method for flux-chamber measurement of ammonia volatilization from putting greens foliarly-fertilized by urea. Clean-Soil Air Water 2017, 45, 1-9. [CrossRef]

54. Kaur, G.; Nelson, K.A.; Motavalli, P.P. Early-season soil waterlogging and N fertilizer sources impacts on corn $\mathrm{N}$ uptake and apparent $\mathrm{N}$ recovery efficiency. Agronomy 2018, 8, 102. [CrossRef]

55. Zhu, Q.; Schlossberg, M.J.; Bryant, R.B. Foliar fertilization-induced injury and recovery of a creeping bentgrass putting green. J. Plant Nutr. 2016, 39, 1589-1596. [CrossRef]

56. McIntosh, M.S. Analysis of combined experiments. Agron. J. 1983, 75, 153-155. [CrossRef]

57. Black, A.S.; Sherlock, R.R.; Smith, N.P.; Cameron, K.C.; Goh, K.M. Effects of form of nitrogen, season, and urea application rate on ammonia volatilization from pastures. New Zeal. J. Agr. Res. 1985, 28, 469-474. [CrossRef]

58. Joo, Y.K.; Christians, N.E.; Bremner, J.M. Effect of urease inhibitors and cationic materials on ammonia volatilization following fertilization of Kentucky bluegrass (Poa pratensis L.) with urea. J. Fert. Issues 1987, 4, 98-102.

59. Liantie, L.; Wang, Z.P.; Van Cleemput, O.; Baert, L. Urea N uptake efficiency of ryegrass (Lolium perenne L.) in the presence of urea inhibitors. Biol. Fertil. Soils 1993, 15, 225-228. [CrossRef]

60. Joo, Y.K.; Christians, N.E.; Blackmer, A.M. Kentucky bluegrass recovery of urea-derived nitrogen-15 amended with urease inhibitor. Soil Sci. Soc. Am. J. 1991, 55, 528-530. [CrossRef]

(c) 2018 by the authors. Licensee MDPI, Basel, Switzerland. This article is an open access article distributed under the terms and conditions of the Creative Commons Attribution (CC BY) license (http://creativecommons.org/licenses/by/4.0/). 